$\begin{array}{lllllllllllllllll}\text { M } & \text { I } & \text { S } & \text { C } & \text { E } & \text { L } & \text { L } & \text { A } & \text { N } & \text { E } & \text { A }\end{array}$

\title{
Antysemicki incydent prasowy. Kartki pocztowe i poznańskie gazety
}

\begin{abstract}
STReszczenie. Jednym z motywów ikonograficznych wykorzystywanych na reklamowych kartach pocztowych z przełomu XIX i XX wieku były strony tytułowe lokalnych gazet. Wokół poznańskich pocztówek z motywem "gazetowym” wydawanych przez Isaaka Plessnera wybuchła w 1904 roku polemika prasowa o silnie antysemickim podłożu. Zarzut dotyczył druku reklamy katolickiego czasopisma u żydowskiego wydawcy.
\end{abstract}

SŁowA KLuczowe: Poznań, antysemityzm, stare pocztówki, reklama, gazety, Isaak Plessner.

Jednym z klasycznych przykładów dekoracyjnego obramowania ${ }^{1}$ widokówek jest motyw rozerwanej koperty (il. 1). Na kartkach z około 1900 roku wydanych przez poznańską firmę „Atlas"2 motyw rozdartej koperty dobrze ilustruje swoistą grę konotacji: oto bowiem z wnętrza koperty wyłaniają się kartki pocztowe z widokami nowego Seminarium Duchownego na Ostrowie Tumskim czy renesansowego Ratusza na Starym Rynku ${ }^{3}$. Rozerwana koperta to oczywisty gwałt na tajemnicy korespondencji, ale przecież umieszczenie wiadomości na kartce pocztowej, zwanej niekiedy „odkrytką", jest $\mathrm{w}$ istocie dobrowolną rezygnacją z tej tajemnicy. Pocztówka pojawiająca się więc $\mathrm{z}$ wnętrza rozerwanej koperty ujawnia i jednocześnie podkreśla swoją specyficzną naturę.

${ }^{1}$ Kartki te różnie bywają nazywane: najczęściej używana - za kolekcjonerami niemieckimi - jest nazwa Pasepartoutkarten lub Vignettekarten.

${ }^{2}$ W zbiorach Biblioteki Uniwersyteckiej w Poznaniu pod sygnaturami Wid-I-0033 i Wid-I-0034.

${ }^{3}$ Kartki te na marginesie zawierają skrót: D.R.G.M. oraz stosowny numer (102794). Oznacza to, że wzór (graficzny) został zarejestrowany w niemieckim urzędzie patentowym i podlegał ochronie prawnej. D.R.G.M. - niem. Deutsches Reichs Gebrauchs Muster - wzór użytkowy Rzeszy Niemieckiej (chroniony prawem od 1891 roku). 


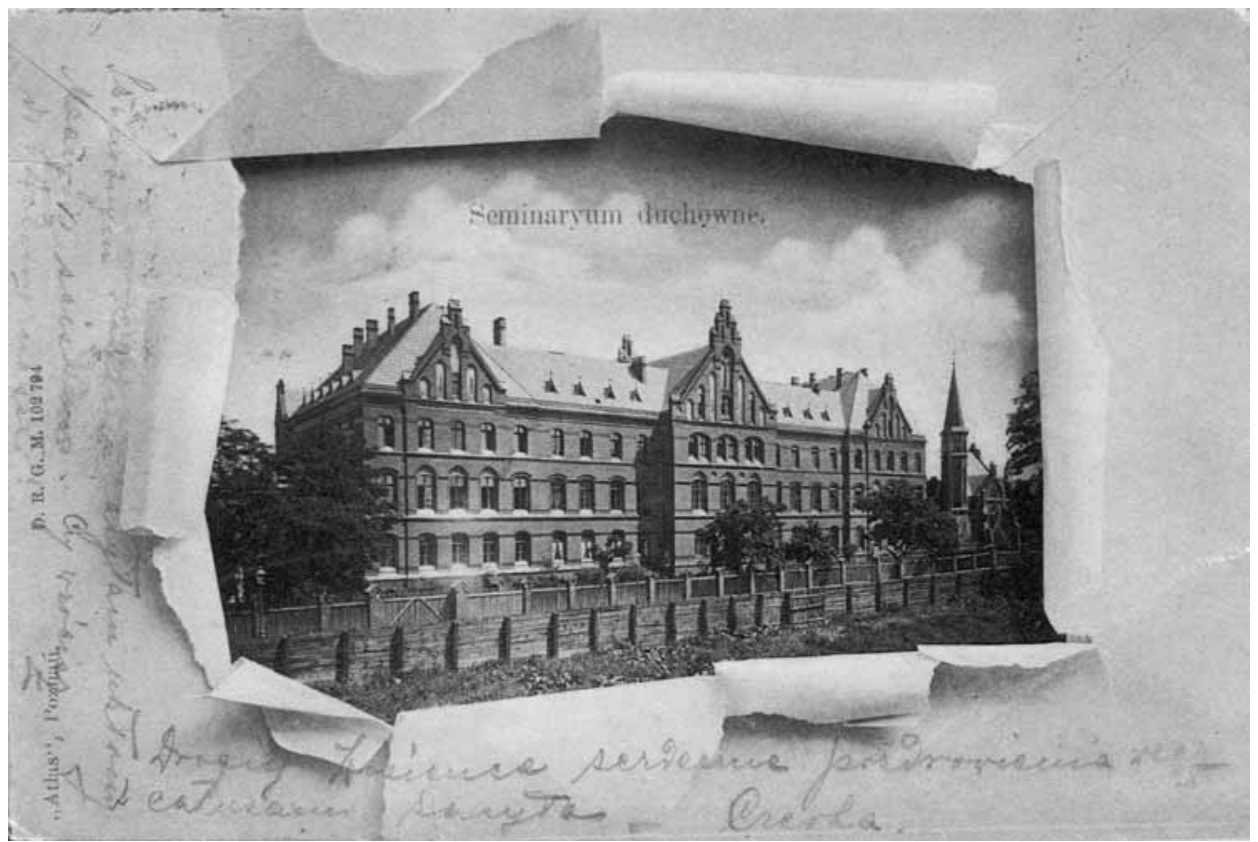

Il. 1. Poznańska widokówka z motywem rozdartej koperty z około 1900 roku

Ten ikonograficzny koncept pojawił się też na innych kartkach, mianowicie na widokówkach $\mathrm{z}$ winietą $\mathrm{w}$ formie strony tytułowej gazety. Pierwotna gra znaczeń gdzieś uleciała, pozostał jedynie motyw rozdartej karty z której wyłania się widok miasta, miejsca, gmachu. W Poznaniu takich kart pocztowych ukazało się co najmniej kilka, ale - co równie interesujące - zostały też wydane dla innych miejscowości wielkopolskich, oczywiście tylko tych, które miały własne, lokalne tytuły prasowe.

Kartka pocztowa Gruss aus Jarotschin. Landratsamt z winietą czasopisma "Jarotschiner Anzeiger. Amtliches Kreisblatt für den Kreis Jarotschin” z 25 czerwca 1902 roku $^{4}$ wydana została przez lokalnego nakładcę R. Traenknera z Jarocina, ale oprócz jego nazwiska u dołu kartki widnieje sygnatura "J. P. jr. / P. 1386".

Jerzy Morgulec w swoim słowniku ${ }^{5}$ uznaje, że „J. P. jr." to tajemniczy, niepotwierdzony żadnymi dowodami istnienia, J. Piętka jr. z Poznania.

${ }^{4}$ E. Czarny, Jarocin na dawnych pocztówkach. Widokówki z lat 1897-1918, Jarocin 2003, s. 105.

${ }^{5}$ J. Morgulec, Słownik nakładców i wydawców pocztówek na ziemiach polskich oraz poloników, cz. 9, Warszawa 2002. 
Z tego samego mniej więcej czasu co pocztówka jarocińska pochodzi kartka z Kościana: Kosten. Kreisständehaus z winietą czasopisma „Kostener Kreisblatt. Amtliches Veröffentlichungsblatt für den Kreis Kosten" z 15 października 1901 roku $^{6}$, również wydana przez lokalnego nakładcę, S. Meyera (il. 2). Kartka ta chroniona jest opatentowanym wzorem D.G.R.M. [nr] 18912 i na marginesie opatrzona sygnaturą drukarza "J. P. jr. i. P. $1256 "$.

Il. 2. Reklamowa kartka pocztowa z motywem rozdartej gazety „Kostener Kreisblatt" z 1901 roku

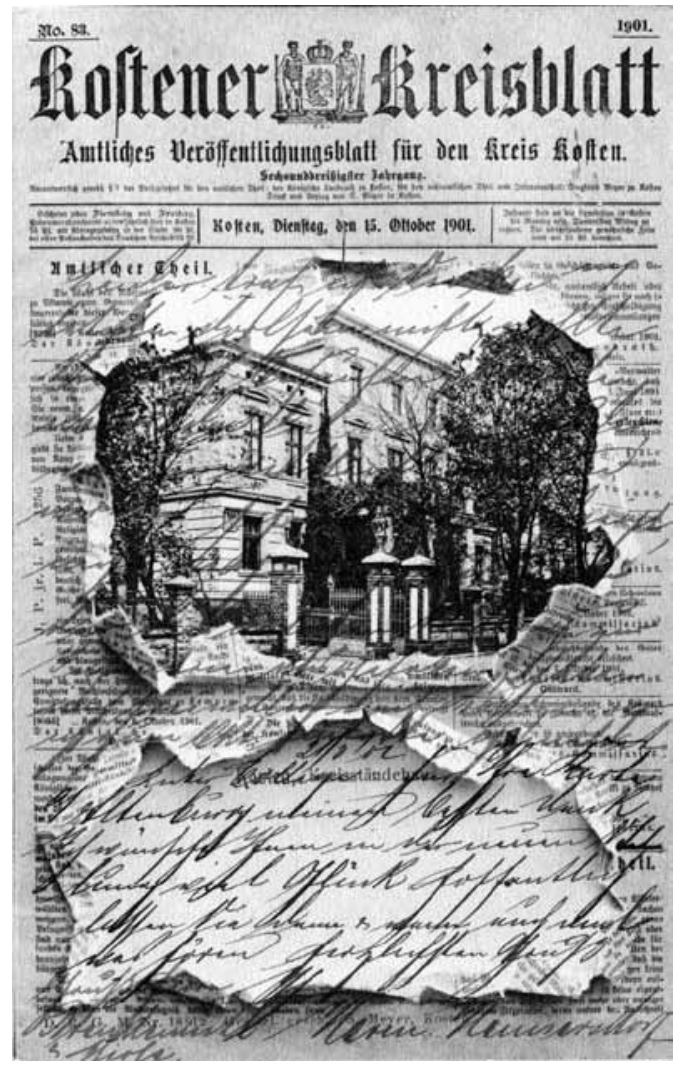

Obie kartki - jarocińska i kościańska - mają identyczny schemat ikonograficzny: tło stanowi strona tytułowa gazety z wyraźnie widoczną winietą tytułu oraz nota wydawnicza. W stronie gazety znajdują się dwie duże dziury: z górnej wyłania się widok gmachư ${ }^{7}$ w dolnej zaś puste pole przeznaczone na korespondencję. Wykonane w technice światłodruku są oczywistym fotomontażem, w którym użyta została zniszczona strona gazety.

\footnotetext{
${ }^{6}$ Kościan na starych pocztówkach, oprac. P. Dobraś, Kościan 2008, s. 124.

${ }^{7} \mathrm{~W}$ obu przypadkach są to siedziby rządów: Landratsamt w Jarocinie to Starostwo Powiatowe, Kreisständehaus w Kościanie to Urząd Stanu Cywilnego.
} 
Jeszcze dobitniej widać to na przykładach poznańskich widokówek $\mathrm{z}$ "gazetowymi" winietami. W zbiorach ikonograficznych Biblioteki Uniwersyteckiej znajduje się kilka tego typu kart pocztowych, przy czym aż cztery to reklamówki „Posener Neueste Nachrichten”, liberalnego dziennika wydawanego od 1899 roku przez Georga Wagnera, i wszystkie powstały w 1901 roku (il. 3).

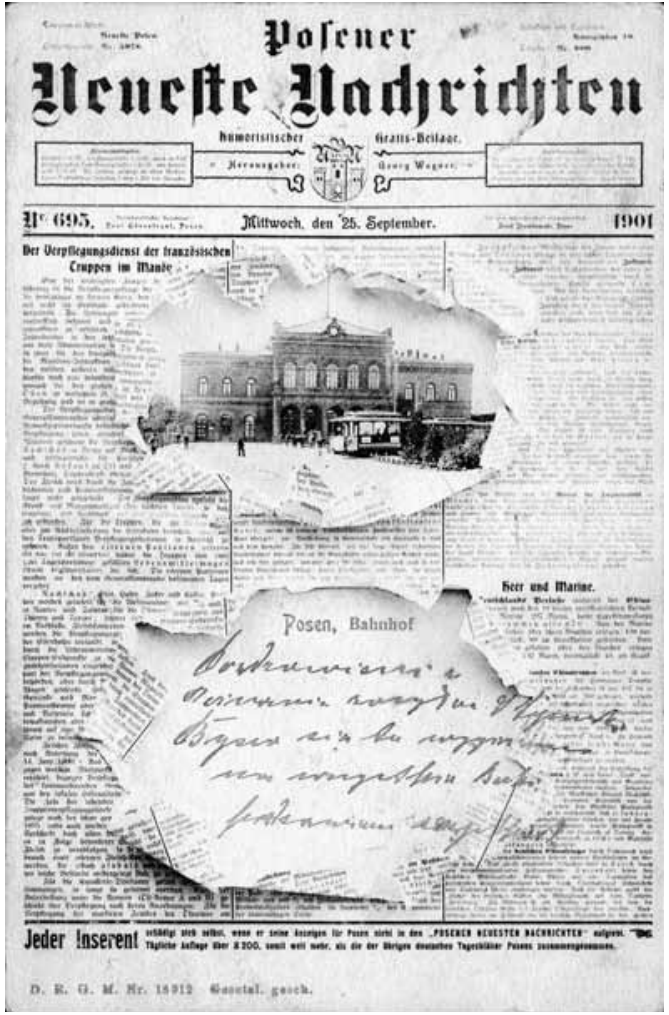

Il. 3. Reklamowa kartka pocztowa z motywem rozdartej gazety „Posener Neueste Nachrichten" z 1901 roku

Pierwsza, z widokiem Odwachu ${ }^{8}$ na Starym Rynku, ma winietę 687 numeru „Posener Neueste Nachrichten” z 15 września 1901 roku, druga, z widokiem fasady dworca kolejowego - winietę 695 numeru z 25 września 1901 roku $^{9}$, a trzecia - ponownie Odwach i winietę 695 numeru z 25 września 1901 roku ${ }^{10}$. Wydawca użył dwukrotnie tej samej strony tytułowej, zmienił jedynie widoczek w wydartej dziurze.

\footnotetext{
${ }^{8}$ Sygnatura Wid-I-1340.

9 Sygnatura Wid-I-0935.

10 Sygnatura Wid-I-0457.
} 
Pomysł ze stroną tytułowa gazety podchwycił Isidor Themal, największy wówczas poznański wydawca kart pocztowych i zaczął wydawać serię Posener Presse, z której w zbiorach Biblioteki Uniwersyteckiej zachował się tylko jeden przykład ${ }^{11}$, mianowicie kartka opatrzona numerem 3 ze stroną „Posener Neueste Nachrichten” z 28 września 1901 roku. Inaczej niż we wszystkich poprzednio przywoływanych przykładach, mamy tu zreprodukowaną niemal w całości stronę tytułową gazety, a zamiast widoku miasta pojawia się fragment codziennego dodatku do gazety „Tägliches Unterhaltungsblatt...". Szeroki margines u dołu kartki, w żaden sposób niewyodrębniony dodatkowo z tła, był zwyczajowo przeznaczony na korespondencję.

W 1901 roku ukazały się w Poznaniu jeszcze inne kartki pocztowe z motywem gazety. W listopadzie tego roku wysłana została kartka Posen. Wallischeibrïcke. Rathaus z winietą czasopisma „Posener Morgen Zeitung. General-Anzeiger für die Provinz Posen”, wydana przez lokalną firmę Verlag J. Plessner jr. ${ }^{12}$, Posen i opatrzona numerem $1206^{13}$. Inaczej niż dotąd, w górnej części strony tytułowej gazety użyte zostały dwa popularne widoki staromiejskie ozdobione secesyjnym ornamentem roślinnym, a miejsce na korespondencję znalazło się tuż poniżej, jakby zasłaniając fragment gazety. W dodatku całość otoczona została jasnym marginesem, tworzącym rodzaj ramy, wręcz cudzysłowu ${ }^{14}$. To na marginesie znajduje się informacja o wydawcy, po raz pierwszy tak wyeksponowana przez użycie czerwonej farby drukarskiej w typografii.

Druga kartka - identycznie sygnowana, lecz opatrzona numerem 1203 jest jedyna, która wydana została z polskimi podpisami: Poznań. Biblioteka Raczyńskich, a w tle ma winietę gazety wydawanej w języku polskim „Przewodnika Katolickiego” (il. 4) ${ }^{15}$.

${ }^{11}$ Sygnatura Wid-I-0597.

12 Jerzy Morgulec (op.cit., s. 18) pisze: „Kunstverlag J. Plessner jr. Breslau XIII. Wrocław, S. 1914-1918, a[rtystyczne] h[eraldyczne]. M. W. K[ilka]d[ziesiąt]. Znany z kart z heraldyką polsko-lit.-ruską. Niech żyje Polska! (również korespondencja na nich w języku polskim z miejscowości wówczas na terenie Niemieć)", a wiec nie zna wcześniejszej działalności poznańskiej Plessnera (oczywiście, jeśli to ta sama postać!). Por. także: Adressbuch der Provinzial Hauptstadt Posen 1904: „Isaac Plessner jr., Papierhandlung en gros, Breslauerstrasse 14 H pt.".

13 Sygnatura Wid-I-0456.

${ }^{14}$ Klasyczna zabawa polegająca na zatarciu granicy między "znaczącym” (signifiant) i „znaczonym” (signifié): czy jest to kartka pocztowa z reprodukcją gazety, czy też jest to gazeta przedstawiona na pocztówce.

15 Sygnatura Wid-I-0936. 


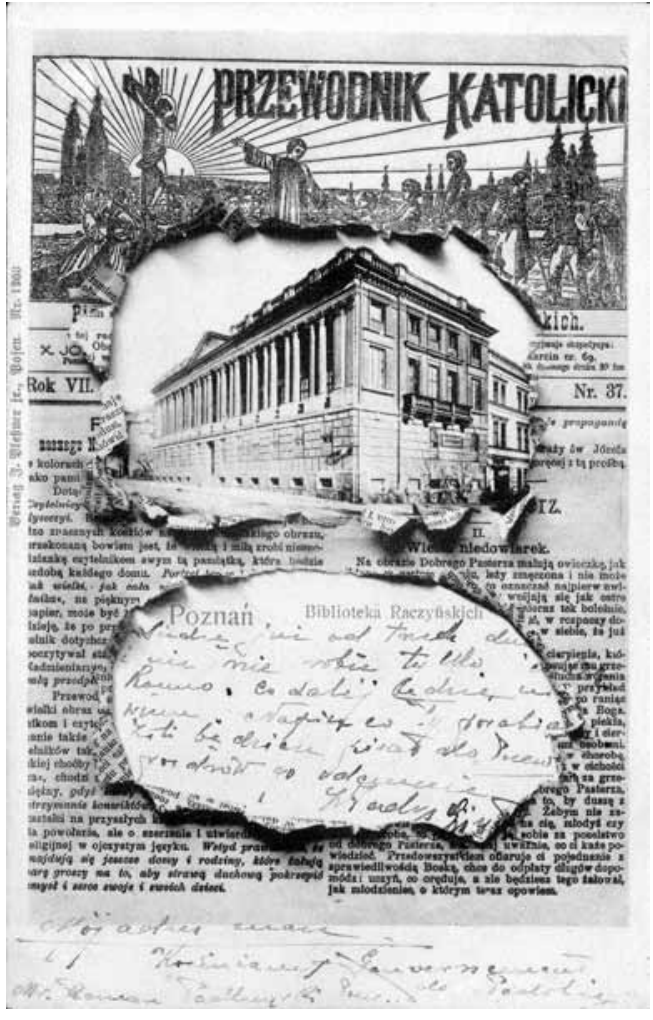

I1. 4. Reklamowa kartka pocztowa „Przewodnika Katolickiego" wydana przez firmę J. Plessner jr. w 1901 roku

Można się domyślać, że dwie nieznane karty Plessnera oznaczone numerami 1204 i 1205 również prezentowały strony poznańskich gazet, a nieodparcie nasuwa się przypuszczenie, że J. Plessner jr. jest tym samym, który drukował kartki jarocińskie i kościańskie (a być może również z innych miast wielkopolskich) dla lokalnych wydawców i sygnował je inicjałami J.P.jr.

Trzy lata później (!), w sierpniu 1904 roku (dziś taki czas zwykło się określać mianem „sezonu ogórkowego”), w prasie poznańskiej wybuchł skandal. Zaskakujący, bo dotyczył zwykłych kartek pocztowych. Popularny „Goniec Wielkopolski” zamieścił w rubryce „Wiadomości potoczne" następującą informację:

Z miasta nadesłano nam dwie karty pocztowe z reklamami dla „Kuryera Poznańskiego" i „Przewodnika Katolickiego”. Obie karty pocztowe wyszły nakładem firmy żydowskiej J.Plesner jr. Posen, nie można przypuszczać, iż bez wiedzy 
i woli tych pism polskich i wysoce katolickich. Karty te przygnębiające wywołują wrażenie, zwłaszcza karta z tytułem „Przewodnika Katolickiego”, na którym po lewej stronie figuruje wizerunek Pana Jezusa ukrzyżowanego, a obok widnieje czerwony napis "Nachahmung verboten” [Naśladownictwo wzbronione - J.S.] ${ }^{16}$, poniżej zaś firma niemiecka. Zaiste dziwić się można, iż pisma polskie i katolickie, które raz po raz nawołują także „swój do swego" taką piękną posługują się reklamą. Karty wykonane są światłodrukami, drukowane nie w Poznaniu ${ }^{17}$.

Oskarżenie było niezwykle dotkliwe, nic więc dziwnego, że „Kuryer Poznański” odpowiedział na zarzut "Gońca...”, informując swoich czytelników,

iż karta ta wyszła bez wiedzy i bez upoważnienia „Kuryera Poznańskiego", iż owa firma żydowska reprodukując swego czasu na kartach widoki zewnętrzne pierwszej strony pism poznańskich, nie zapytała się przytem o pozwolenie "Kuryera", numer zaś użyty do reprodukcji datuje się nie z obecnej chwili, lecz z roku $1901^{18}$.

Publiczna wymiana inwektyw pomiędzy gazetami trwała jeszcze przez jakiś czas i podtrzymywana była podnoszeniem wciąż tych samych zarzutów, a więc, że polskie, katolickie gazety, „Kurier Poznański” i "Przewodnik Katolicki”, zamówiły w wydawnictwie Plessnera produkcję kart pocztowych reklamujących oba tytuły. A czyniąc to, sprzeniewierzyły się głoszonym i propagowanym antysemickim hasłom w rodzaju ,"swój do swego", które w owym czasiebyły widoczną oznaką patriotyzmu.

Najpewniej redaktorzy „Gońca...” nie mieli pojęcia, że Isaak Plessner jr. wydał w 1901 roku kilka, może nawet kilkanaście kartek pocztowych, do których produkcji użył stron tytułowych lokalnych gazet i czasopism. Przynajmniej niektóre z nich były zamawiane przez wydawców z wielkopolskich miasteczek, lecz chyba żadna nie powstała na zlecenie redakcji

${ }^{16} \mathrm{Na}$ żadnym egzemplarzu kartki Plessnera z reprodukcją strony tytułowej gazety takie zastrzeżenie się nie pojawia, ale - najwidoczniej - takie wersje musiały też istnieć. Chyba że autora artykułu poniosła po prostu fantazja czy werwa dziennikarska.

17 Cyt. za: „Kuryer Poznański”, nr 191 z 21 sierpnia 1904. W poznańskich bibliotekach nie zachowały się - niestety - kompletne roczniki "Gońca Wielkopolskiego" i „Tygodnika Katolickiego” z 1904 roku, stąd cała dyskusja cytowana jest za „Kuryerem...”. "Tygodnik...” prawdopodobnie w ogóle nie zajął stanowiska w kwestii zarzutów postawionych na łamach "Gońca...". (W cytowanych fragmentach zachowano pisownię i wyróżnienia w tekście z oryginału).

18 „Kuryer Poznański”, nr 191 z 21 sierpnia 1904. 
czy właściciela gazety jako reklama. Ot, po prostu ikonograficzny koncept. Ale czy mogło to mieć dla kogokolwiek znaczenie?

\title{
JAKUB SKUTECKI
}

\section{Anti-Semitic press incident. Postcards and Poznań press}

\begin{abstract}
Part of the imagery of the genre and one of the iconographic motifs used in advertising postcards (postcards used for advertising purposes) from the turn of the nineteenth and the twentieth century were title pages of local newspapers. In 1904, postcards with this "newspaper" element published by J. Plessner in Poznań provoked though an embittered press polemic around the issue that had a pronounced anti-Semitic character. The issue at stake was that an advertisement of a Catholic journal had been printed by a Jewish publisher.
\end{abstract}

Key words: Poznań, anti-Semitism, old picture postcards, advertising, newspapers, Isaak Plessner. 